$9-4-2020$

\title{
Rwanda's Inyangamugayo: Perspectives from Practitioners in the Gacaca Transitional Justice Mechanism
}

Jean-Damascène Gasanabo

National Commission for the Fight against Genocide (CNLG)

Donatien Nikuze

National Commission for the Fight against Genocide (CNLG)

Hollie Nyseth Brehm

Ohio State University

Hannah Parks

Northeastern University

Follow this and additional works at: https://digitalcommons.usf.edu/gsp

\section{Recommended Citation}

Gasanabo, Jean-Damascène; Nikuze, Donatien; Nyseth Brehm, Hollie; and Parks, Hannah (2020) "Rwanda's Inyangamugayo: Perspectives from Practitioners in the Gacaca Transitional Justice Mechanism," Genocide Studies and Prevention: An International Journal: Vol. 14: Iss. 2: 153-172. DOI:

https://doi.org/10.5038/1911-9933.14.2.1642

Available at: https://digitalcommons.usf.edu/gsp/vol14/iss2/11

This Articles is brought to you for free and open access by the Open Access Journals at Digital Commons @ University of South Florida. It has been accepted for inclusion in Genocide Studies and Prevention: An International Journal by an authorized editor of Digital Commons @ University of South Florida. For more information, please contact digitalcommons@usf.edu. 


\section{Rwanda's Inyangamugayo: Perspectives from Practitioners in the Gacaca Transitional Justice Mechanism}

\section{Acknowledgements}

This article was made possible thanks to the generosity of Aegis Trust programme in Research, Policy and Higher Education as well as DfID and SIDA as project funders. Rwanda's Inyangamugayo:

Perspectives from Practitioners in the Gacaca Transitional Justice Mechanism* Jean-Damascène GASANABO, 1 Donatien NIKUZE, 2 Hollie NYSETH BREHM, 3 Hannah PARKS, 4 1\&2 Research and Documentation Center of Genocide, Rwandan National Commission for the Fight against Genocide (CNLG), 3 Department of Sociology, The Ohio State University 4 Northeastern University *Direct correspondence to Jean-Damascène Gasanabo, Research and Documentation Center of Genocide, Rwandan National Commission for the Fight against Genocide (CNLG), P.O. Box 7035 KIGALI, RWANDA, (email: jd.gasanabo@cnlg.gov.rw) 


\title{
Rwanda's Inyangamugayo: Perspectives from Practitioners in the Gacaca Transitional Justice Mechanism
}

\author{
Jean-Damascène Gasanabo \\ National Commission for the Fight against Genocide (CNLG) \\ Kigali, Rwanda \\ Donatien Nikuze \\ National Commission for the Fight against Genocide (CNLG) \\ Kigali, Rwanda \\ Hollie Nyseth Brehm \\ Ohio State University \\ Columbus, Ohio, USA \\ Hannah Parks \\ Northeastern University \\ Boston, Massachusetts, USA
}

In the aftermath of mass violence, governments and organizations often create transitional justice mechanisms to punish those who committed crimes and mend societal relations. ${ }^{1}$ Although international mechanisms like the International Criminal Court have received much attention, transitional justice efforts have also been utilized as a tool for justice within communities that directly experienced violence. These more localized transitional justice mechanisms have been crucial and are increasingly common, ${ }^{2}$ though comparatively few studies have examined the actors who implement such efforts.

This article focuses on the practitioners of transitional justice in Rwanda's post-genocide Gacaca courts. In the aftermath of the 1994 Genocide against the Tutsi, the government of Rwanda created a historically-informed court system - known as the Gacaca courts - to adjudicate suspected génocidaires: perpetrators of the genocide. Due to the structure of the courts and the lack of available judges to staff them, lay members of each community were elected to preside over the trials as judges (Inyangamugayo). This article draws upon testimonies from 135 of these former lay judges to address two questions: (1) How did the Inyangamugayo perceive their duties? And (2) What challenges did the Inyangamugayo face as they sought to implement these duties? In addressing each question, we pay particular attention to the gendered nature of responses in line with research on gendered approaches to and experiences of roles. As relatively few studies have focused on the experiences of the Inyangamugayo beyond the legal role they played in the Gacaca court system, ${ }^{3}$ this study contributes to an emerging body of scholarship on the practitioners of local transitional justice. ${ }^{4}$ Understanding how the Inyangamugayo viewed their duties, as well as the challenges they met, has the potential to advance knowledge about the Gacaca court processes. Such analysis is also

${ }^{1}$ Phil Clark, The Gacaca Courts, Post Genocide-Justice and Reconciliation in Rwanda: Justice Without Lawyers (Cambridge: Cambridge University Press, 2010), 30; Paul Rutayisire, Gacaca Courts in Rwanda (Kigali: Minister of Justice, 2012$), 19$.

${ }^{2}$ Hollie Nyseth Brehm and Shannon Golden, "Centering Survivors in Local Transitional Justice," Annual Review of Law and Social Science 13, (2017), 103, accessed July 22, 2020, doi: https://doi.org/10.1146/annurev-lawsocsci-110316-113444.

${ }^{3}$ Anuradha Chakravarty, Investing in Authoritarian Rule: Punishment and Patronage in Rwanda's Gacaca Courts for Genocide Crimes (New York: Cambridge University Press, 2015); Kristin Conner Doughty, Remediation in Rwanda: Grassroots Legal Forum (Philadelphia: University of Pennsylvania Press, 2016); Simon Gasibirege, “The Election of Inyangamugayo Judges: Break Up or Continuity?," Notes of the Conflict Management Centre 6, (2002), 93-127; Catherine Honeyman et al., "Establishing Collective Norms: Potentials for Participatory Justice in Rwanda," Peace and Conflict: Journal of Peace Psychology 10, no. 1 (2004), 1-24; Bert Ingelaere, Inside Rwanda's Gacaca Courts: Seeking Justice After Genocide (Madison: University of Wisconsin, 2016).

${ }^{4}$ Erin K. Baines, "The Haunting of Alice: Local Approaches to Justice and Reconciliation in Northern Uganda," International Journal of Transitional Justice 1, no. 1 (2007), 91-114; Patricia Lundy, "Paradoxes and Challenges of Transitional Justice at the 'Local' Level: Historical Enquiries in Northern Ireland," Contemporary Social Science 6, no. 1 (2011), 89-105.

Jean-Damascène Gasanabo, Donatien Nikuze, Hollie Nyseth Brehm and Hannah Parks. "Rwanda's Inyangamugayo: Perspectives from Practitioners in the Gacaca Transitional Justice Mechanism." Genocide Studies and Prevention 14, 2 (2020): 153-172. @2020 
important in its own right, as over 250,000 Inyangamugayo presided over the 1.9 million trials that touched the lives of arguably every Rwandan in the wake of the genocide. ${ }^{5}$

In what follows, we begin with an overview of the Gacaca court system and the Inyangamugayo, followed by a brief discussion of the existing research on judges' perceptions of their roles in other contexts, such as in the national justice system. Next, we describe the 135 randomly selected Inyangamugayo with whom we spoke and the methods that guided our interviews. We begin our results section by discussing the Inyangamugayo's initial perceptions of their duties, highlighting that they perceived accountability and reconciliation as their two main goals. We then address the judges' perceptions of punishment and accountability as well as of reconciliation. We then illustrate some of the perceived challenges these judges faced and suggest how such information can be fruitful for future transitional justice endeavors.

We pay particular attention to the differing perspectives of male and female Inyangamugayo. An examination of gendered perspectives sheds light on the intricacies and complexities of the Gacaca system, including how those staffing the courts viewed it different. Accordingly, throughout the entire article, we illustrate how gender impacted the way in which judges perceived their duties and associated challenges, which we further address in our conclusion.

\section{Background on the Gacaca Courts and the Inyangamugayo}

The 1994 Genocide against the Tutsi claimed over one million lives in a little over three months. ${ }^{6}$ After the violence ended, the newly established Rwandan government attempted to arrest and try suspected genocide perpetrators. The result was the initial incarceration of "more than 125,000 individuals," a number roughly equal to ten percent of the adult male Hutu population at the time. ${ }^{7}$ Rwanda's prison system had been built to accommodate only 15,000 individuals. The large influx of incarcerated persons consequently led to abysmal prison conditions stemming from severe overcrowding. ${ }^{8}$

To facilitate these individuals' trials, the government passed The Organic Law N ${ }^{\circ}$ 08/96 of August 30, 1996 on the Organization of Prosecutions for Offenses Constituting the Crime of Genocide or Crimes against Humanity Committed Since October 1, 1990. ${ }^{9}$ This law divided suspected genocide perpetrators into four categories based on the severity of their crimes. Category 1 was reserved for the "planners, organizers, instigators, supervisors and leaders" of the Genocide against the Tutsi, as well as for "notorious murderers" and those who committed acts of sexual violence, such as rape or sexual torture. Category 2 included those who committed or plotted intentional homicide or carried out assaults that led to their victims' deaths. Those charged with serious, but nonfatal, assaults were placed in Category 3, and Category 4 was reserved for crimes against property, such as arson and looting, though notably the laws were later restructured into three categories, with Category 3 focused on property crime. ${ }^{10}$ This law was passed as a retroactive statute that acted as a basis for the prosecution of genocide perpetrators.

Upon passing this law, the government began trying suspected génocidaires within Rwanda's existing justice system. The first genocide trials took place in December 1996. Between 1996 and 2001, the national court system tried 5,000 suspects. Yet, for every individual tried, another 24 were awaiting trial in an overcrowded prison, and many other suspected perpetrators had yet to

\footnotetext{
${ }^{5}$ See Rutayisire, Gacaca Courts in Rwanda, 116.

${ }^{6}$ Ministry of Local Government, Dénombrement des Victimes du Génocide, Final Report. (Kigali: Rwandan Ministry of Local Government, 2004), 21.

${ }^{7}$ Mark A. Drumbl, “Punishment, Postgenocide: From Guilt to Shame to 'Civis' in Rwanda," N.Y.U. Law Review 75, (2000), 1287.

${ }^{8}$ Clark, The Gacaca Courts, 99-100.

${ }^{9}$ Law on the Organization of Prosecutions for Offences constituting the Crimes of Genocide or Crimes against Humanity committed since October 1, 1990 of 1996 (Organic Law No. 8/96), August 30, 1996, (Rep. of Rwanda), accessed July 30, 2020, https:// reparations.qub.ac.uk/assets/uploads/ORGANIC-LAW-No.pdf.

${ }^{10} \mathrm{Ibid}$. Eventually, these categories were collapsed into three categories (with Categories 2 and 3 combined into Category 2 and Category 4-pertaining to crimes of property - becoming Category 3). See also Clark, The Gacaca Courts, 72-73.
} 
be found. ${ }^{11}$ This proved challenging, as Rwanda's legal apparatus had been decimated during the genocide. When the violence subsided, a mere 12 prosecutors had remained in the country, along with only 244 judges - less than one third of the number that had been in the country during the previous year. ${ }^{12}$ Additionally, only 22 percent of judicial support staff, who assisted judges and state prosecutors, remained alive or in the country. ${ }^{13}$

Working under these constraints, the government thus decided to turn toward a traditional justice mechanism known as the Gacaca courts. "Gacaca" is a Kinyarwanda word that loosely translates to "justice on the grass." Prior to colonialism, Gacaca courts were a tool of communal mediation and conflict resolution for civil disputes throughout rural Rwanda. In these courts, village elders would listen to the disputes of all parties and would then agree upon a solution, including appropriate reparations. Though Gacaca courts were structurally replaced by a Europeanstyle court system when Rwanda fell under colonial rule, they continued to informally operate throughout the colonial period..$^{14}$

Given the cultural relevance of Gacaca courts and the large caseload post-genocide, the government decided to modify this traditional court system to try individuals suspected of participating in the genocide. The new Gacaca court system had strong ties to the state but, like the previous system, would operate on a local level. Specifically, the government established 12,103 Gacaca courts (known as Inkiko Gacaca but shortened here to Gacaca) across the country. ${ }^{15}$

\section{The Inyangamugayo}

As the government created Gacaca, it was faced with the important decision of ascertaining who would staff the courts. Eventually, the government decided lay members of the community, known as Inyangamugayo, would serve as judges. Just like the concept of Gacaca, the concept of Inyangamugayo is tied to Rwandan culture. Although the term is typically translated to "person of integrity" or "the uncorrupted," it is semantically complex, and the word "integrity" in English does not express its full meaning. For instance, according to the National Itorero Commission (the main institution that conveys knowledge about Rwandan culture), the term Inyangamugayo refers to a person endowed with qualities or behaviors of ubumuntu (humanity), ubupfura n'imico myiza (honesty and good manners), kwiyoroshya (modesty), ubudahemuka (loyalty), gushishoza (discernment), ubutabera (justice), ukuri (truthfulness), kubaha umuryango (respect for the family), kubaha uburenganzira bwa muntu (respect for human rights), kwihangana (patience), kunyurwa (satisfaction), kuzuza inshingano (responsibility), kwitanga (dedication), ishyaka (enthusiasm or determination), and kujya inama (confidentiality), among other positive virtues. ${ }^{16}$

In pre-colonial Gacaca trials, the Inyangamugayo were typically respected village elders. ${ }^{17}$ In line with this practice, the post-genocide government modified the Gacaca courts and asked

\footnotetext{
${ }^{11}$ Aneta Wierzynska, “Consolidating Democracy through Transitional Justice: Rwanda's Gacaca Courts,” N.Y.U. Law Review 79, no. 5 (2004), 1955.

${ }^{12}$ Hollie Nyseth Brehm, Christopher Uggen, and Jean-Damascène Gasanabo, “Genocide, Justice, and Rwanda's Gacaca Courts," Journal of Contemporary Criminal Justice 30, no. 3 (2014), 335.

${ }^{13}$ Charles Villa-Vicencio et al., Building Nations: Transitional Justice in the African Great Lakes Region (Cape Town: Institute for Justice and Reconciliation, 2005), 86.

${ }^{14}$ Clark, The Gacaca Courts, 53.

${ }^{15}$ For more on the genocide, see Alison Des Forges, Leave None To Tell the Story: Genocide in Rwanda (New York: Human Rights Watch, 1999) 6-591, accessed July 31, 2020, https://www1.essex.ac.uk/armedcon/story id/Leave\%20None\%20 to\%20tell\%20the\%20story-\%20Genocide\%20in\%20Rwanda.pdf; Helen M Hintjens, "Explaining the 1994 Genocide in Rwanda," The Journal of Modern African Studies 37, no. 2 (1999), 241-286; Filip Reyntjens, "Rwanda: Genocide and Beyond," Journal of Refugee Studies 9, no. 3 (1996), 240-251; Philip Verwimp, "An Economic Profile of Peasant Perpetrators of Genocide: Micro level Evidence from Rwanda," Journal of Development Economics 77, no 2 (2005), 297323. For more on Gacaca, in addition to the works cited elsewhere, see Jennie E. Burnet, "The Injustice of Local Justice: Truth, Reconciliation, and Revenge in Rwanda," Genocide Studies and Prevention 3, no. 2 (2008), 173-193; Lars Waldorf, “Mass Justice for Mass Atrocity: Rethinking Local Justice as Transitional Justice," Temple Law Review 79, (2006), 1-88.

${ }^{16}$ National Itorero Commission, Imfashanyigisho yo gutoza Indangagaciro y'Ubunyangamugayo (Kigali: Ubutore Development Centre, National Itorero Commission, 2014), 1-28.

${ }^{17}$ Notably, in traditional Gacaca, the Inyangamugayo were men. In the significantly altered post-genocide version, both men and women could serve in this position. See, Paul Christoph Bornkamm, Rwanda's Gacaca Courts: Between Retribution and Reparation (London: Oxford University Press, 2012), 32.
} 
communities to elect Inyangamugayo from their respective sectors and cells (small geographic units within Rwanda). Community members were eligible to serve as Inyangamugayo if they fulfilled the following qualifications, as stipulated in Article 7 of Presidential Order Number 12/01 of June 26, 2001:

a) To be of Rwandan nationality;

b) To have his or her residence in the cell where he or she needs to present his or her candidature;

c) To be at least 21 years of age;

d) To be a person of good morals and conduct;

e) To be truthful and characterized by a spirit of sharing;

f) Not to have been sentenced to a penalty of at least six (6) months of imprisonment;

g) Not to have participated in genocide or other crimes against humanity;

h) To be free from sectarianism; and

i) To have no history of indiscipline. ${ }^{18}$

Though legal training was required in the national courts, legal training was not a prerequisite for service in Gacaca. In fact, the judges did not need to be literate, as one's character was regarded as more important than educational background. According to Ngarambe, ${ }^{19}$ qualifying as Inyangamugayo meant that one should possess a number of characteristics, including but not limited to "maturity, honesty, equity, trustworthiness, dependability, truthfulness, and other moral principles." Similarly, Porte ${ }^{20}$ explains the Inyangamugayo were expected to exhibit courage, honor, justice, and truth.

In 2001, 169,442 individuals were elected to serve as Inyangamugayo. ${ }^{21}$ Following their election, the Rwandan government provided a brief period of formal training. ${ }^{22}$ The training covered the objectives and functions of the Gacaca courts as well as legal ethics. ${ }^{23}$ As the Inyangamugayo were tasked with gathering evidence, identifying suspects, summoning suspects to court, holding court hearings, presiding over trials, and ascertaining sentences, the training also included practical instructions regarding how to undertake the duties associated with their new positions.

After the training sessions, the Inyangamugayo undertook pilot trials in which they worked on gathering evidence and testing the Gacaca model. Then, in 2005, the Inyangamugayo began holding trials on a weekly basis in communities across Rwanda, ultimately adjudicating 1,958,634 cases between 2002 and 2012. ${ }^{24}$ Notably, the benches of judges originally held nineteen people, though this number dwindled over time to seven and, for some courts, five. Note also that judges were continually elected as it became clear that some judges had to step down due to accusations of genocide or inappropriate behavior.

\section{Research on Inyangamugayo and on Judges' Gendered Perceptions of Roles}

Early research on the Inyangamugayo focused on elections ${ }^{25}$ and perceptions. ${ }^{26}$ For instance,

${ }^{18}$ Establishing Modalities for Organizing Elections of Members of "Gacaca Jurisdictions" Organs of 2001 (Presidential Order No. 12/10), July 26, 2001, (Rep. of Rwanda).

${ }^{19}$ Telesphore Ngarambe, Practical Challenges in Customary Law Translation: The Case of Rwanda's Gacaca Law (Addis Ababa, Ethiopia: Organization for Social Science Research in Eastern and Southern Africa, 2015), 83.

${ }^{20}$ Elisabeth Porter, Peacebuilding: Women in International Perspective (Routledge Advances in International Relations and Global Politics), 1st ed. (New York: Routledge, 2007), 175.

${ }^{21}$ Bert Ingelaere, "The Gacaca Courts in Rwanda," in Traditional Justice and Reconciliation after Violent Conflict: Learning from African Experiences, ed. Luc Huyse and Mark Salter. (Stockholm, Sweden: International Institute for Democracy and Electoral Assistance, 2008), 41.

${ }^{22}$ Initial training lasted six days, though subsequent trainings were implemented to respond to the needs of the Inyangamugayo and better equip them to undertake their duties. See Bornkamm, Rwanda's Gacaca Courts, 38.

${ }^{23}$ National Service of Gacaca Courts, Amasomo y'Inyangamugayo z'Inkiko Gacaca (Training of Inyangamugayo of Gacaca Courts) (Kigali: National Service of Gacaca Courts, November-December, 2005), 7-93.

${ }^{24}$ National Service of Gacaca Courts, Summary of the Report Presented at the Closing of Gacaca Courts Activities (Kigali: National Service of Gacaca Courts, 2012), 5; See also Bornkamm, Rwanda's Gacaca, 46.

${ }^{25}$ Gasibirege, The Election, 1.

${ }^{26}$ Honeyman et al., Establishing Collective Norms, 5. 
Honeyman and colleagues ${ }^{27}$ conducted interviews with thirty-nine Inyangamugayo to assess their perceptions of their training, as well as their initial perceptions of the courts. This "preliminary investigation" 28 documented initial worries of the Inyangamugayo, such as a lack of formal education, limited training, and their own security. The study likewise found that although many judges were initially skeptical of the process, they expressed hope that Gacaca could bring justice, noting that it would "resolve the problem of not punishing people" and "help reconcile Rwandans." ${ }^{29}$

Since then, most studies of the Inyangamugayo have been conducted within broader analyses of the Gacaca court system. Doughty documented, for instance, how the Inyangamugayo exhibited improvised and ambiguous authority in their role. ${ }^{30}$ The Inyangamugayo did not have any formal legal training. However, they did receive many months of legal education from the Rwandan government prior to their eligibility to judge in a courtroom setting. Their authority to improvise in ambiguous situations was crucial to the process of obtaining truth and accountability, which Palmer $^{31}$ notes were core to how the judges saw their role.

Chakravarty addressed some of the benefits of serving as a judge, suggesting that some Inyangamugayo would subsequently serve in local positions of leadership following service on a Gacaca court bench due to their elevated position within their community. She likewise illustrated how some judges used their role to help family members in terms of legal advice and counsel. Furthermore, she enumerates how the judges struck the precarious balance between giving some "procedural leeway to the defendant" and protecting "the procedural rights of the accusers." 32 Moreover, Ingalaere ${ }^{33}$ highlighted the complex interplay between state forces and local factors that shaped courts across Rwanda, and added important insights into understanding the context in which the Inyangamugayo worked. ${ }^{34}$

Here, we depart from the important studies cited above to focus specifically on how the Inyangamugayo viewed their duties and on the impediments to enacting those duties as voiced by Inyangamugayo. To be clear, while research has addressed the Inyangamugayo, very few studies to our knowledge have specifically focused on how these individuals themselves viewed their roles, especially after they had enacted them. Palmer ${ }^{35}$ provides an important exception. After interviewing fifty Inyangamugayo and state Gacaca officials, Palmer suggested that the judges viewed finding the truth and obtaining accountability as the main justifications for gacaca, which in turn impacted how they viewed their roles. Given the size of the sample and the fact that the interviews occurred while Gacaca was ongoing, additional studies are warranted. Indeed, within literature on judging more broadly, how judges view their roles is an important line of inquiry, as it provides a window both into how individuals view themselves and into the actions they take within the role (such as case outcomes).

Much of this general literature on judging relies upon role theory. Role theory proposes that human behavior is guided by expectations of individuals and society. ${ }^{36}$ Individuals within any society occupy collectively recognized roles, or "structured behavioral model(s) relating to a certain position of an individual in an interactional setting." ${ }^{37}$ In essence, roles provide expectations about how an individual should behave and how they should interact with others.

\footnotetext{
${ }^{27}$ Ibid., 6.

${ }^{28}$ Ibid., 2.

${ }^{29}$ Ibid., 15.

${ }^{30}$ Doughty, Remediation in Rwanda, 191-225.

${ }^{31}$ Nicola Palmer, Courts in Conflict: Interpreting the Layers of Justice in Post-Genocide Rwanda (New York: Oxford University Press, 2015).

${ }^{32}$ Chakravarty, Investing in Authoritarian Rule, 299.

${ }^{33}$ Ingelaere, Inside Rwanda's Gacaca Courts, 12.

${ }^{34}$ Ibid., 98-116.

${ }^{35}$ Palmer, Courts in Conflict, 149.

${ }^{36}$ Bruce J. Biddle, “Recent Developments in Role Theory," Annual Review of Sociology 12, no. 1 (1986), 67.

${ }^{37}$ Milton Yinger, Toward a Field Theory of Behavior: Personality and Social Structure (New York: McGraw Hill, 1965$), 49$.
} 
Judicial roles constitute the normative expectations shared by judges regarding how a given judicial office should be performed. ${ }^{38}$ Judges' attitudes and role orientations have long been tied to their decision-making. ${ }^{39}$ Though it is not possible to empirically test how judges' role orientations in Rwanda were associated with their decisions given the lack of data on judicial decision-making across courts, we suggest there is value in understanding how the judges of Rwanda's Gacaca courts approached their roles more broadly. Indeed, Gomes and co-authors ${ }^{40}$ argue that examining how judges perceive their role is important to understanding how they address their work and the broader institutions in which they work.

Notably, roles in any social context are gendered, and a vast body of research has documented that gender impacts perceptions and lived experiences. ${ }^{41}$ In terms of gender and judging, research has likewise established that men and women judges may view their roles differently. While some studies have shown that there is not a significant distinction in terms of sentences imposed by men or women judges and jurors, research has found that they do weigh factors differently when determining a punishment. According to Steffensmeier, for instance, women look at cases more holistically, considering factors such as the perpetrator's likelihood to offend again or their criminal background when deciding a verdict. Men, on the other hand, tend to focus more on the facts and evidence of the particular case before them..$^{42}$ In fact, a judiciary comprised solely of men will yield different results as opposed to one made up of equal numbers of men and women, leading Martin to suggest that women need to be better incorporated into justice systems. ${ }^{43}$

Schultz and Shaw take this line of thinking a step further by examining case studies from fifteen different countries around the world and find that the gendered differences in role perception, particularly in the judicial realm, is a global phenomenon. ${ }^{44}$ In line with this scholarship, we expect that men and women Inyangamugayo in Rwanda viewed their roles differently. While many people have addressed the roles of women in post-genocide Rwanda, ${ }^{45}$ scholarship has yet to address how gendered norms associated with men and women shaped judges' perceptions of and experiences with Gacaca. Though we are unable to consider gendered differences in sentencing in this paper, we take the important first step in analyzing gendered differences in views of their roles-including the punitive or restorative nature of Gacaca.

Accordingly, we turn toward interviews with the Inyangamugayo of Rwanda's Gacaca courts to ascertain how they viewed the roles they held for upwards of a decade. We focus specifically on how they saw their duties and on the challenges they faced in implementing these duties.

\footnotetext{
${ }^{38}$ J. Woodford Howard Jr., "Role Perceptions and Behavior in Three US Courts of Appeals," The Journal of Politics 39, no. 4 (1977), 916.

${ }^{39}$ James L. Gibson, “Judges' Role Orientations, Attitudes, and Decisions: An Interactive Model,” American Political Science Review 72, no. 3 (1978), 911.

${ }^{40}$ Adalmir Oliveira Gomes et al., "Judicial Work and Judges' Motivation: The Perceptions of Brazilian State Judges," Law \& Policy 38, no. 2 (2016), 163.

${ }^{41}$ Christine R. Barker et al., Gender Perceptions and the Law (Aldershot: Ashgate Publishing, 1998); Darrell Steffensmeier and Chris Hebert, "Women and Men Policymakers: Does the Judge's Gender Affect the Sentencing of Criminal Defendants?" Social Forces 77, no. 3 (1999), 1163-1196, accessed July 31, 2020, doi: 10.2307/3005975; Fionnuala Ní Aoláin, The Oxford Handbook of Gender and Conflict (London: Oxford University Press, 2017); Gender Monitoring Office, The State of Gender Equality in Rwanda: From Transition to Transformation (Kigali: Gender Monitoring Office, March 2019), 7-50, accessed July 31, 2020,http://gmo.gov.rw/fileadmin/user upload/Researches\%20and\%20Assessments/ State\%20of\%20Gender\%20Equality\%20in\%20Rwanda.pdf; Liberata Gahongayire, "Combatting Gender Based Violence in Rwanda," International Journal of Development and Sustainability 1 no. 2 (2012), 417-436; Patricia Yancey Martin, et al., "Gender Bias and Feminist Consciousness Among Judges and Attorneys: A Standpoint Theory Analysis," Signs: Journal of Women in Culture and Society 27, no. 3 (2002), 665-701, accessed July 3, 2020, https://doi. org/10.1086/337941; Ulrike Schultz and Gisela Shaw, Gender and Judging (Oxford: Hart Publishing, 2017).

${ }^{42}$ Steffensmeier, Women and Men Policymakers, 1183-1184.

${ }^{43}$ Martin et. al., Gender Bias and Feminist Consciousness, 668.

${ }^{44}$ Schultz and Shaw, Gender and Judging, 11.

${ }^{45}$ Marie E. Berry, “When 'Bright Futures' Fade: Paradoxes of Women's Empowerment in Rwanda,” Signs: Journal of Women in Culture and Society 41, no. 1 (2015), 1-27; Jennie E. Burnet, "Gender Balance and The Meanings of Women in Governance in Post-genocide Rwanda," African Affairs 107, no. 428 (2008), 361-386; Catharine Newbury, and Hannah Baldwin, "Confronting the Aftermath of Conflict: Women's Organizations in Postgenocide Rwanda," in Women and Civil War: Impact, Organizations, and Action, ed. Krishna Kumar (Boulder, CO: Lynne Rienner 2001), 97-128.
} 
Throughout, we evaluate how the judges saw their roles and how they believed they should have interacted with others. We also pay particular attention to gendered differences in views of roles and challenges.

\section{Research Methods}

To analyze how the Inyangamugayo perceived their duties and to understand the challenges they faced, we conducted semi-structured interviews with a selection of 135 former Gacaca judges. Participants were selected using stratified random sampling, utilizing Gacaca court records to randomly select judges from four sectors-Gikondo, Gahanga, Masaka, ${ }^{46}$ and Mwurire. ${ }^{47} \mathrm{We}$ chose these sectors due to their proximity to Kigali and their variation in urbanicity. Gikondo is urban, Mwurire is rural, and Gahanga and Masaka are both semi-urban, with roughly half of their residents residing in urban areas and half residing in rural areas. Though we originally sought to assess variation in responses across urban and rural locations, the location did not impact any of the findings we present here. This may be due to the fact that most of the locations are still relatively near Kigali, something that future research could address in more detail.

Using a list of all Gacaca court trials in each sector, we randomly selected twenty trials from each of the four sectors using a random number generator. Then, working from the Gacaca court archives in Kigali, we identified all Inyangamugayo involved in the randomly selected trials.

After the identification of the Inyangamugayo, we worked with local contacts to obtain their addresses. We then contacted each individual and asked if they would be willing to participate in the study. Voluntary participation and anonymity were emphasized. Three individuals declined participation in the study, while five were not able to participate because they were not home. Those who participated were assigned pseudonyms, and identifying details were redacted from transcriptions to preserve their anonymity.

Overall, 135 Inyangamugayo participated in this study. Their ages ranged from thirty-three to eighty-six years old with an average age of fifty. Eighty of the Inyangamugayo were men, and fifty-five were women. Although it can be sensitive to discuss ethnicity in Rwanda today, ${ }^{48}$ the participants' experiences during the genocide enabled us to identify their ethnic and national identities. For instance, many respondents addressed whether they were part of the targeted group during the genocide, while others volunteered that they were Hutu or Tutsi. We thus ascertained that sixty-seven of the judges we interviewed were Tutsi while sixty-four of them were Hutu. Four were born in other countries (Burundi, Uganda, and the Democratic Republic of the Congo) and did not discuss a clear ethnic identity.

Twenty-nine of these individuals served in Gikondo, thirty-two served in Gahanga, thirtyfour served in Masaka, and forty served in Mwurire. Our sample represented judges in both cell and sector courts, as well as in the court of appeals. ${ }^{49}$ Forty-one participants were judges at the cell courts; sixty-three participants were judges at sector courts (among them seventeen started at cell level and then moved to sector level); and thirty-one participants were judges at the courts of appeals (most of whom also served at sector level).

Interviews were conducted between June and December of 2015 and in June 2016 by a small team of American and Rwandan researchers. Interviews took place in or around each participant's

${ }^{46}$ The Rwandan administration entities include four provinces (Northern, Southern, Eastern, and Western Provinces) and the City of Kigali. Each province is divided into districts, and the latter is divided into sectors. Each sector is also divided into cells, and the cells are divided into villages. Gikondo, Gahanga, and Masaka are sectors in Kicukiro District, which is based in the City of Kigali.

${ }^{47}$ Mwurire is a sector in Rwamagana District based in the Eastern Province.

${ }^{48}$ National laws passed in Rwanda deem ethnic categories as tied to genocide ideology, and the census does not include ethnicity. See Law on the Crime of Genocide Ideology and Related Crimes of 2018 (Law No. 59/2018), August 22, 2018 (Rep. of Rwanda), 66-77, accessed July 30, 2020, https://rwandalii.africanlii.org/sites/default/files/gazette/OG\%2Bno\%2BS pecial\%2Bof\%2B25\%2B09\%2B2018.pdf; Timothy Longman, Memory and Justice in Post-Genocide Rwanda (New York: Cambridge University Press, 2017), 168-170.

${ }^{49}$ The Gacaca courts were established at the cell and sector levels (levels of geographic administration akin to villages and counties) to enable localized trials. It was the responsibility of the cell courts to try less grievous crimes against property belonging to Category 3 (originally Category 4), while sector courts tried Category 1 and Category 2 crimes (although many Category 1 offenses were also tried by the ordinary courts). See Palmer, Courts in Conflict, 100. 
home and followed a semi-structured interview guide that included questions about their duties as judges, their opinions of court procedures and outcomes, and their perceived impact of the courts. The interviews typically lasted between one and two hours and were conducted in Kinyarwanda or English via a translator. Respondents were given the option to conduct interviews in French as well, though no respondents chose to do so. Despite the different linguistic backgrounds of researchers conducting the interviews, we did not encounter any major differences in respondents' accounts across interviewers.

Interviews were recorded and transcribed. Then, we repeatedly read each interview and the corresponding field notes to identify key themes as well as ascertain consistent patterns throughout the testimonies. This analysis ultimately yielded the data presented in this article, and the outcomes we include represent the most prominent findings with relation to perceptions of roles as well as perceptions of challenges. As noted above, we limited the locations of research to areas within driving distance of Kigali to facilitate ease of data collection. The results of this study are consequently not generalizable to all Inyangamugayo across Rwanda but rather to Inyangamugayo who served in the four sectors included in this study.

\section{Results: Inyangamugayo in the Gacaca Courts}

We begin by briefly exploring respondents' recollections of their initial assumptions and ideas regarding their roles in Gacaca. Though other scholars cited above have studied initial perceptions, it is nonetheless important to include initial perceptions to contextualize judges' notions of roles at the end of the Gacaca court process. Next, we examine the respondents' notions of punishment and accountability - core aspects of the job according to our interviewees. This is followed by an analysis of their perceptions of reconciliation at individual and societal levels, as these aspects of the role were particularly prominent for interviewees as well. Finally, we reflect on challenges that participants raised associated with the implementation of judges' roles. Throughout, we highlight gendered differences in respondent perceptions.

\section{Initial Notions of the Judicial Role}

In many interviews, participants reflected on their initial thoughts upon hearing the government's plans to implement the Gacaca courts. Some Inyangamugayo were optimistic about the court system's potential to bring punitive justice, and numerous respondents explained that they had initially believed the Gacaca courts would be able to punish those who committed crimes of genocide. For instance, one Inyangamugayo shared that he and some of his fellow judges originally thought that, "Gacaca had the potential to respond to the crimes-to bring justice to victims and punish the perpetrators." ${ }^{50}$ Similarly, a judge interviewed in 2016 told us that when she first heard of Gacaca, she considered "...some people waiting [in] prison that had never participated in genocide. So, [I] thought they were going to be given justice and come back home." ${ }^{51}$

Although some respondents recalled hope and optimism regarding Gacaca's potential to hold people accountable for crimes of genocide, many respondents described their initial skepticism regarding Gacaca's ability to aid reconciliation, much in line with findings in other studies. ${ }^{52}$ For instance, a judge interviewed shared, "[w]hen Gacaca was beginning, I thought that it was impossible to live with someone who harmed you...[i]t was so hard to imagine that Gacaca would be able to help the survivors and the genocide perpetrators restore their relationships." ${ }^{53}$ One Inyangamugayo described the courts' potential to contribute to the reconciliation process as so unimaginable that it was akin to "a dream," 54 as he could not see how Gacaca could help "solve the problem." 55 Another

\footnotetext{
${ }^{50} \mathrm{KAM}$, interview with respondent, Gahanga Sector, June 15, 2015.

${ }^{51}$ DPF, interview with respondent, Masaka Sector, June 06, 2016.

${ }^{52}$ Honeyman et al., Establishing Collective Norms, 15; Doughty, Remediation in Rwanda, 191-225.

${ }^{53}$ HEM, interview with respondent, Gahanga Sector, June 15, 2015.

${ }^{54}$ GPM, interview with respondent, Mwurire Sector, June 13, 2016.

${ }^{55}$ Ibid.
} 
participant explained, "I thought Gacaca was unable to respond...I said that it is impossible to stand in front of the one whose relatives were killed by you or to face those who killed your relatives." 56

Despite these initial notions regarding the potential of the court system, many of the judges recalled positive emotions tied to their election. Generally, men expressed pride in being asked to serve in the role, often viewing the service as a patriotic duty to their country. Notions of serving one's country are often gendered; indeed, in Rwanda, the majority of the military and police forces are men. ${ }^{57}$ In line with this, over half of all men interviewed noted that they were excited to be elected as judges specifically because they wanted to serve their country and because they believed it was their duty to help rebuild it. One respondent shared that he "felt so proud [to be] saving the country by stepping into Gacaca courts activities," 58 for instance, while another explained that he "wish[ed] to participate in Gacaca court because Gacaca would be my opportunity to serve my country." 59 By becoming judges, respondents believed they were taking on the responsibility of righting the wrongs that had been committed. As one judge described, "It was not easy for [us], but because we had a duty to serve our country, but because it was us [Rwandans] who had caused the problem, we [Rwandans] had to find a solution to those problems we had caused." ${ }^{60}$

Women were likewise often pleased to be elected, but their happiness more commonly stemmed from pride that their neighbors trusted and respected them to serve in the role. In other words, women's positive feelings were generally tied to what they believed their election signified about their social capital rather than service to the government. While women were more likely to express initial hesitation when it came to their election as a judge, twenty-five of the fifty-five women interviewed noted in their responses that they felt honored to be chosen, as it indicated that their community thought highly of them. For instance, as one Inyangamugayo explained,

I was very happy because they were calling us Inyangamugayo; people of integrity...I think we were elected because we are people of integrity. It depended on the way we interacted with neighbors. They could see that we were people of integrity; Inyangamugayo. I never studied laws, I had never been a lawyer, but they trusted me and elected me. It is because I was living in harmony with neighbors, and I was a person of integrity according to them. I think that is why I was elected. ${ }^{61}$

Another female judge acknowledged the potential boost to social capital that coincided with participating in the courts, noting that she "was happy with [being elected] because when you are in those positions, even at that experience, you get exposure and then experience." ${ }^{62}$ For many women, being elected to be a judge was an opportunity to gain respect amongst their neighbors, though some women did also invoke notions of serving their country. As one woman described, "If the whole country [is] trusting you that you are Inyangamugayo, that you are a person of integrity, that is something big to me."63

Likely due to gendered norms about who was fit to judge, women were also more likely than men to express reluctance about the role. One female judge reflected on her election:

I tried to refuse serving as a judge...I said that I cannot, because I see it as something that can have a negative impact on my life and I was saying that I could not marry both my work and adequately fulfill the Gacaca duties at the same time. I tried to resist and refuse serving as a judge, but finally, I accepted and became convinced. ${ }^{64}$

\footnotetext{
${ }^{56}$ BGM, interview with respondent, Gikondo Sector, June 10, 2015.

${ }^{57}$ BVF, interview with respondent, Gikondo Sector, June 10, 2015.

${ }^{58}$ GCM, interview with respondent, Gahanga Sector, June 15, 2015.

${ }^{59}$ HSM, interview with respondent, Gahanga Sector, June 15, 2015.

${ }^{60} \mathrm{HCM}$, interview with respondent, Gahanga Sector, June 15, 2015.

${ }^{61} \mathrm{GIF}$, interview with respondent, Gikondo Sector, June 10, 2015.

${ }^{62} \mathrm{BJF}$, interview with respondent, Mwurire Sector, June 13, 2016.

${ }^{63} \mathrm{CMF}$, interview with respondent, Mwurire Sector, June 13, 2016.

${ }^{64} \mathrm{KEF}$, interview with respondent, Mwurire Sector, June 13, 2016.
} 
Other women expressed that they were initially nervous about the possibility of retaliation from the people they tried in court. For instance, many women judges explained that the people they were trying could harm them or even kill them, which we address in more detail below.

Men were comparatively far less reluctant to serve, or at least less likely to recall reluctance or nervousness upon being elected. This difference may indicate gendered notions of bravery, and it is difficult to know whether these sentiments were genuine or whether they reflect pressure to discuss a lack of apprehension. As one judge explained, "No. We were not nervous. We had decided to do that, and we knew we were doing what we were supposed to be doing: truth telling, trying cases. We had no problem doing that." ${ }^{65}$ Others emphasized that they were not worried upon their election because they felt prepared for the role. As one judge described, "I was never worried at all because we could take fair decisions and even before taking decisions I could investigate. I was never worried at all." ${ }^{66}$ This confidence was explicitly expressed by approximately one third of all men who were interviewed. ${ }^{67}$

For some men, the threat of retaliation was also of little consequence to them because they believed that if anything did happen to them as judges, the perpetrators would be brought to justice. ${ }^{68}$ In fact, sixty-three of the eighty men interviewed-over seventy-five percent of the male sample-noted that they did not experience any fear when it came to taking on the role of Inyangamugayo and that the concept of facing any form of retaliation from perpetrators or their families was of no concern to them. Some even boasted that they welcomed it, as they knew there were systems in place to protect them or to see justice served. ${ }^{69}$ As one judge described, "yes we were worried that they might even kill you, but again we had security." ${ }^{\prime 70}$ Another man described this sentiment by noting, "even the government was there to protect us, to help us too, to be safe;"71 while another judge similarly explained, "I think some people hat[ed] me. I did not care. I know I was protected. We had a fair government that protected us, so I was not worried about one hating me." 72

Generally, this suggests that men may have placed comparatively more trust in state institutions. Men with whom we spoke to generally trusted the police, the government, and the systems in place to protect them more so than the female Inyangamugayo. ${ }^{73}$ Even if they were aware of potential dangers tied to the role, many male respondents were by and large confident that they would be protected.

\section{Duties Throughout: Punishment and Accountability}

Turning toward how the judges saw their roles, punishment surfaced prominently during the interviews as a central duty. Indeed, many of the judges discussed the importance of their duty to punish those who were responsible for the genocide. This involved discussions of fair punishments and confessions as well as more limited discussions of acquitting those who were not guilty.

Numerous respondents (Gikondo Sector, 2015) perceived the courts - and thus their associated duties - as punitive in nature, commenting that the objective of the Gacaca courts was "to punish people for the crimes they committed"74 and noting that they "thought it was a good strategy to punish those who participated in the genocide." ${ }^{\prime 5}$ Many of the Inyangamugayo we interviewed likewise mentioned the importance of Gacaca in ending the "culture of impunity"76 in Rwanda. One participant exemplified this perspective by explaining,

\footnotetext{
${ }^{65}$ BLM, interview with respondent, Mwurire Sector, June 15, 2016.

${ }^{66}$ RWM, interview with respondent, Gikondo Sector, June 11, 2015.

${ }^{67}$ CONF, consolidated interview results, June 2015-2016.

${ }^{68}$ RE\&PU, consolidated interview results, June 2015-2016.

${ }^{69}$ PROT, consolidated interview results, June 2016.

${ }^{70} \mathrm{KEM}$, interview with respondent, Mwurire Sector, June 14, 2016.

${ }^{71}$ HAM, interview with respondent, Mwurire Sector, June 16, 2016.

${ }^{72}$ KJVM, interview with respondent, Mwurire Sector, June 15, 2016.

${ }^{73}$ TRUS, consolidated interview results, June 2015-2016.

${ }^{74}$ DJM, interview with respondents, Gikondo Sector, June 10, 2015.

${ }^{75}$ SJBM, interview with respondents, Gikondo Sector, June 10, 2015.

${ }^{76} \mathrm{KIM}$, interview with respondents, Gikondo Sector, June 10, 2015
} 
In Rwandan history, killings of the Tutsi population happened in 1959, in 1963, in 1973, and during the 1994 genocide...Killers were never arrested or brought to justice for sporadic massacres of Tutsi that took place in the years before the 1994 genocide. There was total impunity. After the genocide, things have changed. ${ }^{77}$

Even though both men and women discussed punishment and accountability, men were more likely to view their major role as bringing individuals to justice. One judge stated, "I did not want to see people walking in the street after killing others. I wanted them to be punished. I wanted the victims to get justice." 78 Another saw his duty as offering some form of retribution for individuals who were witnesses or victims and wanted to see "justice be given to those who were victims of the genocide."79 Reflecting a similar belief that victims would receive relief from punishment and accountability, one judge stated,

I had to make sure I [gave] people justice especially to those who were victims of the crimes that were committed. No one was there to do that apart from [us]... I had to play that role because during those difficult situations we were supposed to participate in solving the problems that were in place. That motivated me. ${ }^{80}$

Men's emphasis on accountability and punishment was generally not intertwined with a focus on rehabilitation, however. The emphasis was instead placed on the process of giving punishments and the speed with which they did it. ${ }^{81}$ For instance, a judge from Mwurire sector in 2016 explained that he primarily enjoyed the role "because I contributed to justice. I saw many perpetrators being tried and taken to prisons." ${ }^{2}$ This justice-based view of the role of the judge was shared by nearly sixty of the eighty men interviewed. As another explained, it was "a matter of bringing justice so that [perpetrators] would face some punishments." 83 In this sense, the way in which they perceived their duty emphasized ensuring that justice was adequately served.

Women also discussed punishment, though their general focus was placed less on administering retributive justice and instead emphasized giving fair, impartial sentencing that they believed would eventually result in reconciliation and more restorative forms of justice. Approximately forty of the fifty-five women interviewed expressed that their main responsibility as Inyangamugayo was to ensure that perpetrators were restoratively punished and eventually could be integrated back into society and help the community to rebuild. ${ }^{84}$ Many explained that they had a duty to society to facilitate the reconciliation process to the best of their ability. One woman compared Gacaca sentencing to "giving [the perpetrators] medicine...I was happy with that because you cannot kill everybody that participated..." ${ }^{85}$ Another woman judge explained, "[i]f he deserves the punishment, then Gacaca [will] punish him or her." 86 Yet, the female judges also tended to view their role as judges more holistically, seeing the importance not only in ensuring that perpetrators were punished, but also in community rebuilding and reconciliation, as we further explain below in more detail. These results align with Steffensmeier's finding that, in the judicial system, women are more likely to view cases more holistically. ${ }^{87}$

As respondents discussed impunity, numerous judges also highlighted the importance of fair punishments. Some judges thought that punishments were too harsh, while others lamented that

\footnotetext{
${ }_{77} \mathrm{KIM}$, interview with respondent, Gikondo Sector, June 10, 2015.

${ }^{78} \mathrm{HDM}$, interview with respondent, Mwurire Sector, June 16, 2016.

${ }^{79} \mathrm{BVF}$, interview with respondent, Gikondo Sector, June 11, 2015.

${ }^{80} \mathrm{KEM}$, interview with respondent, Gahanga Sector, June 02, 2016.

${ }^{81}$ Speed was one of the government-stated goals of Gacaca. Likely due to this explicit prioritization, the vast majority of respondents discussed the importance of swift justice.

${ }^{82}$ KJMVM, interview with respondent, Mwurire Sector, June 14, 2016.

${ }^{83}$ MAM, interview with respondent, Gikondo Sector, June 10, 2015.

${ }^{84}$ PUNI, consolidated interview results, June 2015-May 2016.

${ }^{85} \mathrm{ADF}$, interview with respondent, Gahanga Sector, June 02, 2016.

${ }^{86} \mathrm{NMF}$, interview with respondent, Gikondo Sector, June 10, 2015.

${ }^{87}$ Steffensmeier, Women and Men Policymakers, 1176.
} 
they were too light. Yet, most believed the punishments were fair. Furthermore, men and women alike were generally satisfied with the punishments they meted out. ${ }^{88}$

When prompted to comment on the fairness of their punitive measures, one judge responded, "[a]ll punishments fit the crime. At the beginning, sentences ranged from 18 to 30 years of imprisonment. After the policy of granting leniency to those who confessed was implemented, sentences were reduced, usually to less than 18 years... depending on the crime." ${ }^{89}$ Many others held similar views and praised the sentences, suggesting they were fair and lenient. For instance, one participant expressed, "[t]he strength of Gacaca [is] in the quality of justice it gave to people. For those who confessed and plead guilty, their sentence was reduced. For example, a defendant who was faced with 12 years of imprisonment may have only been sentenced for 6 years due to confession." 90

At the same time, several Inyangamugayo highlighted their duty of acquitting innocent people. Many judges shared that it was not uncommon for those who did not actually participate in genocide to be accused..$^{91}$ Mention of this phenomenon was not necessarily gendered, but it was brought up in the interviews of approximately ten percent of both the women and men who responded..$^{2}$ Specifically, there was concern that innocent people had been convicted of serious crimes, and the Inyangamugayo who mentioned this concern felt they were among the only people who had the potential to rectify this. For instance, one interviewee described a case in which two men had been involved in a conflict involving money. One of the men was so resentful that he accused the other of participating in the genocide. The judge explained,

... there was someone who wanted his neighbor to be convicted because they had a conflict. Throughout the trial, many witnesses came and testified in favor of the accused, arguing that he never participated in the genocide. The brother of the one who was accusing his neighbor revealed that the accused never participated in the genocide and revealed the existing conflict between the defendant and the plaintiff. We based on this testimony and we acquitted the accused person. ${ }^{93}$

Thus, acquitting those who were innocent was seen as an important duty, though it was much less commonly cited than punishing those who were guilty of crimes of genocide.

Duties Throughout: Reconciliation

Reconciliation also surfaced prominently as a major part of the judges' roles. In the years after the genocide, but prior to the establishment of Gacaca, social relationships were dangerously strained from genocidal violence and other acts of betrayal. As one interviewee explained, "[a]fter the genocide, relationships [between Hutu and Tutsi] were not good. I remember Hutu were hiding ... relations were tense." ${ }^{94}$ Judges likewise recalled that survivors hid as well, fearing further violence. Considering these tensions, many judges believed that one of their main duties was to contribute to reconciliation. One judge demonstrated this understanding by commenting that his responsibility was "to reconcile people first." ${ }^{25}$ Another Inyangamugayo explained, "...during the genocide, people were separated...After the Gacaca hearings, people managed to reconcile to the extent that, today, they can interact peacefully." 96

As noted above, women were especially likely to discuss reconciliation, with seventy percent of all women who responded highlighting this as a priority of their role in their responses. Many of the women judges with whom we spoke believed that Gacaca gave victims and perpetrators a

\footnotetext{
${ }^{88}$ SATI, consolidated interview results, June 2015-2016.

${ }^{89} \mathrm{KEM}$, interview with respondent, Gahanga Sector, June 02, 2016.

${ }^{90} \mathrm{TDM}$, interview with respondent, Gikondo Sector, June 11, 2015.

${ }^{91}$ ACQU, consolidated interview results, June 2015-2016.

${ }^{92}$ AMWP, consolidated interview results, June 2015-2016.

${ }^{93} \mathrm{VM}$, interview with respondent, Mwurire Sector, June 15, 2016.

${ }^{94}$ TJPM, interview with respondent, Gikondo Sector, June 10, 2015.

${ }^{95} \mathrm{BLM}$, interview with respondent, Mwurire Sector, June 15, 2016.

${ }^{96} \mathrm{GCM}$, interview with respondent, Gahanga Sector, June 15, 2015.
} 
platform to face each other and try to find a way to move forward together. Gacaca served to "bring them together and try to discuss their problems, their issues." ${ }^{\prime 97}$ As judges, they believed their responsibility was to facilitate this process. One woman highlighted this difference in priorities by stating, "[a]s duties, I have to reconcile first. I have to reconcile people first and, second, to listen to those who have problems and try to mediate survivors with perpetrators." ${ }^{98}$

Many women likewise felt that they "were helping people to heal." ${ }^{99}$ One female judge from Gahanga Sector in 2016 explained,

Gacaca played a big role in integrating people who thought that they were cast out of the society, so Gacaca tried to integrate those people who were possibly shamed. Because when the survivor and the perpetrator were before the Gacaca court, they could even greet each other and try to discuss the issues concerning what happened for both. ${ }^{100}$

Although women were more likely to invoke reconciliation, both men and women Inyangamugayo expressed several ways through which they believed their work as judges, as well as Gacaca in general, influenced the reconciliation process. ${ }^{101}$ Though women were more likely to discuss the role of dialogue, men also discussed how Gacaca facilitated dialogue and, in turn, reconciliation. Beyond dialogue, the fact that Inyangamugayo were both Hutu and Tutsi was cited as a significant unifying aspect of Gacaca. One participant stated, "[a]nother thing which I liked about Gacaca was that judges were both Hutu and Tutsi. Judges were not from one side..."102 Still, others explained that punishment was necessary to facilitate societal reconciliation, highlighting the overlap in punitive and restorative justice. For instance, one respondent shared

I thought Gacaca was very important because people deserved to be punished, and it [Gacaca] was a good idea because it came with an objective of reconciling victims and perpetrators. It was true justice that allowed enemies to live together... and I think it even helped to restore security. ${ }^{103}$

Taken together, although women were more likely to discuss reconciliation, many judges believed that aiding reconciliation was a major aspect of their role.

\section{Challenges Implementing Judicial Roles}

Finally, while discussing their perceptions of their duties as Inyangamugayo in the Gacaca courts, respondents often reflected on their perceived challenges. Although numerous challenges surfaced, three challenges were particularly relevant to judges' discussions of their roles. These included the issues associated with encouraging truth telling, with punishing their neighbors, and with volunteering a large amount of their time to their positions. ${ }^{104}$

Turning first to challenges linked to specific aspects of their duties, numerous judges discussed issues they faced when asking fellow community members to tell the truth during trials $-\mathrm{a}$ sentiment that was shared equally among men and women judges. Truth telling was vital because the judges were restricted to relying solely on eyewitness testimony. For example, when explaining how the judges reached their decisions, an Inyangamugayo shared, "[w]e based our judgments on the testimonies from the community and also heard the defendants themselves. Then, after the public hearings, we discussed in private, referred to all the information collected from the community, and-based on the relevant provisions of the law - we made our decision." 105

\footnotetext{
${ }^{97} \mathrm{KJF}$, interview with respondent, Gahanga Sector, June 13, 2015.

${ }^{98} \mathrm{KJF}$, interview with respondent, Gahanga Sector, June 13, 2015.

${ }^{99} \mathrm{HEAL}$, consolidated interview results, June 2015-2016.

${ }^{100} \mathrm{ALF}$, interview with respondent, Gahanga Sector, June 01, 2016

${ }^{101}$ RECO, consolidated interview results, June 2015-2016.

${ }^{102}$ RIM, interview with respondent, Gikondo Sector, June 10, 2015.

${ }^{103}$ MSF, interview with respondent, Gahanga Sector, May 31, 2016

${ }^{104}$ CHAL, consolidated interview results, June 2015-2016.

${ }^{105}$ MAM, interview with respondent, Mwurire Sector, June 17, 2016
} 
However, many Inyangamugayo commented on the fact that “...people were not willing to give testimony." 106 One participant shared, "I also got annoyed in some cases because there are those who could attend trials but who did not want to give information." ${ }^{107}$ Another participant explained,

[m]aking files and gathering information was a very difficult task. Hutu were not willing to share information [about what happened]. Some Tutsi also hesitated and thought they might get flashbacks, making it very difficult to get information. We sensitized people to tell us what they saw. By that time, people did not trust each other. ${ }^{108}$

Numerous judges offered reasons behind this difficulty. One Inyangamugayo asserted, "[o]f course it was very difficult to testify against your neighbors. It depended on what you were going to say and anticipating the reaction of the public. For example, if you are going to testify against someone who killed a human being and someone who killed a goat, of course the two carried different weight.".109 Another Inyangamugayo explained, "...many people could not reveal information because they never wanted to...create that grudge between neighbors." 110

Given the need to use eyewitness testimony, the judges had to take it upon themselves to encourage truth telling. When witnesses were unwilling to speak or give testimony, the Inyangamugayo often explained why it was a vital component of the Gacaca court process. ${ }^{111}$ For example, a judge stated, "[b]efore the trial, I always tried to explain to the community the importance of truth telling. Afterward, there were some who could speak, who could open up and tell everything that happened." 112 Again, this narrative was shared among both men and women who were serving as judges. They broadly believed that individuals telling the truth greatly improved the effectiveness of the Gacaca process and thus their jobs.

Additionally, numerous judges commented on the difficulties they faced when trying to punish individuals within their communities. Some had been conscious of the burden of trying their neighbors since the inception of Gacaca. ${ }^{113}$ For instance, one participant explained, "[w]hen I was first elected, I was fearful, thinking that I would face problems if suspects, based on the outcomes of their trials, held grudges against me or tried to harm me."114

Generally, this sentiment was more widely held among women-in fact, thirty-two of the fifty-five women respondents expressed direct fear that their involvement in Gacaca would result in direct harm to them or their families, which again may reflect gendered differences in expressing fear. ${ }^{115}$ Some men expressed similar sentiments, and although some suggested that their fears were unfounded, other judges expressed concerns that linger today. One Inyangamugayo noted, "I have to be cautious because of someone I tried and punished during the Gacaca courts. He and his relatives were always against me, saying that I did wrong things against them. Because of that, I have to be cautious."116 Another judge similarly noted, "Some keep grudges against us and our families...we remain apprehensive of possibly being hurt, being victimized by the families who were accusing us of doing wrong things against their [accused] members." ${ }^{117}$ Another former judge summarized these issues by explaining,

\footnotetext{
106 TEST, consolidated interview results, June 2015-2016

${ }^{107}$ TAM, interview with respondent, Gikondo Sector, June 10, 2015.

${ }^{108}$ NEM, interview with respondent, Gikondo Sector, June 10, 2015.

${ }^{109}$ MFF, interview with respondent, Masaka Sector, June 06, 2016.

${ }^{110}$ There were likely other reasons as well. For instance, many people may have wanted to avoid retraumatization. UHF, interview with respondent, Gikondo Sector, June 11, 2015.

${ }^{111}$ SJDM, interview with respondent, Gikondo Sector, June 11, 2015

${ }^{112}$ SJDM, interview with respondent, Gikondo Sector, June 11, 2015

${ }^{113}$ TAM, interview with respondent, Gikondo Sector, June 10, 2015.

${ }^{114}$ KIM, interview with respondents, Gikondo Sector, June 10, 2015

${ }^{115}$ SJBM, interview with respondents, Gikondo Sector, June 10, 2015

${ }^{116}$ DJM, interview with respondents, Gikondo Sector, June 10, 2015

${ }^{117}$ BVF, interview with respondent, Gikondo Sector, June 11, 2015.
} 
[i]t was very difficult to work as an Inyangamugayo judge for the Gacaca courts. Can you imagine having to judge and punish neighbors, friends and family members? In addition, remember that judges prosecuted genocide perpetrators who had family members in our villages. ${ }^{118}$

Furthermore, we heard stories of judges who explained they were verbally intimidated and harassed. For instance, a judge shared, "I received messages announcing that the families of the defendant would kill me. The family members of the perpetrators sent me some messages telling me that one day we will kill you because of what you are doing."119 There is some evidence that at least some people who threatened the judges were punished via the ordinary (i.e., national) court system. For example, during the first half of 2006, 761 people were arrested for criminal acts they had committed against genocide survivors, witnesses, and Inyangamugayo. ${ }^{120}$ Other respondents suggested that there were still ongoing problems within their communities at the time of the interviews, illustrating challenges that lingered long after the courts closed. ${ }^{121}$

In line with women's increased likelihood to discuss a fear tied to their elections, women were also more likely to discuss a fear of repercussions due to grudges from the trials they presided over. One woman reflected on someone she sent to prison, worriedly explaining, "[m]aybe he will one day get out and kill me, I do not know; maybe he will."122 Another woman described the challenges they faced as judges and the often-overwhelming feelings of fear and doubt that they would be saddled with:

[y]eah, it was a difficult task. It was a difficult task because there was a time when judges were persecuted. I could ask, will the government protect us? Are we going to be protected by the state, because our life is in danger? It happened here but again we had to continue. We had to continue serv[ing]. ${ }^{123}$

For some women, this fear became too great and they had no choice but to relocate for the safety of their family, as one judge shared, "I even wanted to relocate from this place and go to another place, I could hear people talking about how I participated in making sure that they would be taken to prison. I remember I wanted to relocate and go to another place."124 Again, it is difficult to differentiate between whether women were more likely to hold such fears or whether gendered norms about expressing fears allowed them to do so more easily. Such differences may also stem from women's likelihood to be the primary caregivers and thus express greater concern about their family. It also may have been less effective to threaten the male judges because, as mentioned previously, they generally wielded greater confidence in the systems in place and felt sure that they would either be protected or avenged should they be killed as a result of their role.

Finally, the majority of the judges - men and women alike-shared an overarching, general challenge associated with the fact that serving as a judge with the Gacaca courts often required the judges to sacrifice their personal time. ${ }^{125}$ As one interviewee explained,

[d] uring the trial phase, the hearing itself represented an entire day's work. Inyangamugayo spent the whole day without even a break for food or drink. In addition, another two days were spent preparing reports on completed cases, studying the dossiers for upcoming cases, writing summons to witnesses, and formalizing the agenda for trials. Despite all of this, Inyangamugayo returned empty handed at the end of the day. ${ }^{126}$

\footnotetext{
${ }^{118}$ TAM, interview with respondent, Gikondo Sector, June 10, 2015.

${ }^{119}$ MLF, interview with respondent, Gahanga Sector, June 03, 2016.

${ }^{120}$ Rutayisire, Gacaca Courts in Rwanda, 144.

${ }^{121}$ MAM, interview with respondent, Gahanga Sector, June 03, 2016.

${ }^{122}$ BVF, interview with respondent, Gikondo Sector, June 11, 2015.

${ }^{123}$ MJF, interview with respondent, Mwurire Sector, June 15, 2016.

${ }^{124}$ KIM, interview with respondent, Gikondo Sector, June 10, 2015.

${ }^{125}$ SACR, consolidated interview results, June 2015-2016.

${ }^{126}$ JPM, interview with respondent, Gikondo Sector, June 10, 2015.
} 
Inyangamugayo worked without pay while the Gacaca courts were in session. As such, they continuously made personal sacrifices. As one Inyangamugayo revealed, "[w]e [Inyangamugayo] were interested in finding out the truth and punishing genocide perpetrators because of the atrocities they had committed against their neighbors, and we are sure our goal was reached. Yet, there are many things we missed because of acting as Inyangamugayo in the Gacaca courts." 127

Most notably, judges who relied upon subsistence farming lamented the time they were not able to spend working because of the time they were dedicating to Gacaca, ${ }^{128}$ Several of the judges even went so far as to suggest that they were more susceptible to bribery due to the immense financial strain placed on them by their judicial duties. ${ }^{129}$ As one Inyangamugayo stated, "I wish there was a small remuneration granted to judges who participated in the Gacaca process because even those who were caught up in corruption did it because they were not given even a single penny."130 Indeed, participants shared that many defendants tried to bribe Inyangamugayo to influence their verdicts and sentencing. ${ }^{131}$ Those who did take bribes were supposed to be removed from the bench, ${ }^{132}$ and judicial corruption tarnished the reputations of some Inyangamugayo, possibly even threatening the legitimacy of their entire bench. ${ }^{133}$ While none of the judges interviewed admitted to accepting bribes in any form, one did comment that he believed the men were more likely to be bribed, noting that "men may be easy to be corrupted but women will be there to help the people... be fair, fighting [against] corruption and bribery in a court."134 This suggests that women may have been viewed as having more integrity and were less likely to be offered a bribe, though again additional research would be needed to confirm such a claim.

To be clear, many respondents believed that not being paid was not enough of a reason to take bribes. As one participant countered, "[ $\mathrm{t}]$ aking bribes was not caused by working voluntarily. It was caused by a lack of integrity. It was a matter of honesty." ${ }^{135}$ Nevertheless, numerous interviewees made a link between taking bribes and a lack of payment.

More broadly, when asked about suggestions for how the Gacaca courts could have been improved, the most common response across respondents was to offer a small amount of compensation for the judges who volunteered their time every week for 10 years. ${ }^{136}$ Though gendered notions of men as providers may suggest that men would have been more likely to make this claim, it surfaced equally across men and women. Some participants explained that they did receive medical insurance, a bicycle, and/or radio receivers. ${ }^{137}$ Others noted they had been told they would also be grouped into cooperatives with the intention of generating financial revenue to economically support the judges and their families. ${ }^{138}$ However, after the closing of the Gacaca courts, most of the judges we interviewed claimed they did not receive any benefits from these cooperatives. ${ }^{139}$ Some shared that most of the money has since been withdrawn, while others explained that they were still waiting to be grouped into a cooperative. ${ }^{140}$

\footnotetext{
${ }^{127}$ MAM, interview with respondent, Gahanga Sector, June 03, 2016.

${ }^{128}$ FARM, consolidated interview results, June 2016.

${ }^{129}$ BRIB, consolidated interview results, June 2015-2016.

${ }^{130}$ BGM, interview with respondent, Gikondo Sector, June 10, 2015

${ }^{131}$ VERD, consolidated interview results, June 2015-2016.

${ }^{132}$ To ensure impartial judgments from the Gacaca courts, the National Service of Gacaca Courts (NSGC) dismissed any judges who were found to be taking bribes and informed the relevant authorities of their prosecution. According to a 2012 report by the National Service of Gacaca Courts (NSGC), out of the 169,442 judges, 443 were dismissed for corruption, See Rutayisire, Gacaca Courts in Rwanda, 194.

${ }^{133}$ MAM, interview with respondent, Gahanga Sector, June 03, 2016.

${ }^{134}$ TAM, interview with respondent, Gikondo Sector, June 10, 2015.

${ }^{135}$ RWM, interview with respondent, Gikondo Sector, June 11, 2015.

${ }^{136}$ COMP, consolidated interview results, June 2015-2016.

${ }^{137}$ REMU, consolidated interview results, June 2015-2016.

${ }^{138}$ COOP, consolidated interview results, June 2016.

${ }^{139}$ BENE, consolidated interview results, June 2015-2016.

${ }^{140}$ MONE, consolidated interview results, June 2015-2016.
} 


\section{Discussion and Conclusion}

This article aimed to examine how the Gacaca court judges perceived their roles, as well as the challenges they believe they faced when implementing their positions. As such, it examined the Gacaca courts through the eyes of the people who presided over trials and consequently made the courts possible. In doing so, it likewise centered gendered differences in men and women judges' perceptions.

When it comes to their initial perceptions, women were more likely to be reluctant to serve as judges and to express fear about doing so. Men, on the other hand, more commonly discussed their roles in terms of a patriotic duty and to exude pride for serving their country. These differences likely stem from gendered notions about patriotism and duty, as well as gendered ideas of who can express fear. As we suggest, men were also more likely to have confidence in the institution of the state, which is a common finding in many parts of the world. ${ }^{141}$

Turning to the views of their roles, many of the Inyangamugayo with whom we spoke believed that their roles were most intimately tied to punishment and reconciliation. Indeed, numerous judges emphasized the importance of punishment and, specifically, the duty to help eradicate impunity. However, men were more likely to view their role as tied to punishment, while women were more likely to discuss the importance of reconciliation. Many explained that bringing people together was paramount to peaceful coexistence, and some judges likewise noted the importance of having both Tutsi and Hutu on the bench. These gendered distinctions likely reflected gendered ideas within Rwandan society, and additional research would be needed to assess how they impacted the judges' decisions.

Notably, these findings diverge from Palmer's findings, ${ }^{142}$ which documented that Inyangamugayo were most likely to discuss truth-telling and accountability (though general accountability not typically tied to punishment) as their major aims of Gacaca. Judges in this study did indeed discuss truth-telling, but it was typically discussed in connection with punishment, which Palmer did not find to be the case. The difference in the size of the sample, ${ }^{143}$ the timing of the study, or other factors may drive such distinctions across studies, and additional research should seek to identify the factors associated with judges' views of their roles.

Finally, regardless of how they viewed their roles, we highlight how the judges' efforts to enact these roles were not without problems. Many Inyangamugayo expressed the challenge of encouraging truth-telling, which was key to their duties and something that both men and women expressed. Many Inyangamugayo also recalled experiencing verbal harassment in their communities. This challenge is associated with the lack of anonymity of the judges in the Gacaca courts and was more commonly expressed by women. In particular, the Inyangamugayo were elected specifically for having been known and respected within the community. While trials taking place within communities have the potential to make witnesses and judges vulnerable to recrimination from suspects and their families, on the other hand, it encourages transparency through "greater public oversight than in classic courts." ${ }^{144}$ Thus, the intimate nature of these community courts can be thought of as a double-edged sword - an important finding for other community courts worldwide.

It should be noted that despite common experiences and themes that arose throughout the interviews, how Inyangamugayo viewed their roles and their challenges is certainly influenced by factors such as age, gender, class, and residence. ${ }^{145}$ Though we consider gendered differences in this article, future research on the Inyangamugayo and the Gacaca system could focus on other underresearched areas. This scholarship could also analyze how community members viewed the judges for a more holistic picture of the role, and it could likewise expand beyond urban areas. Though we do not see any reason for our findings to be biased by our largely urban sample, researchers should

\footnotetext{
${ }^{141}$ ASSU, consolidated interview results, June 2015-2016.

${ }^{142}$ Palmer, Courts in Conflict, 149.

${ }^{143}$ See Ibid, 13-14. We cannot identify precisely how many Inyangamugayo were interviewed, though they were part of a larger sample of 50 that included other populations.

${ }^{144}$ Timothy Longman, “An Assessment of Rwanda's Gacaca Courts," Peace Review 21, no. 3 (2009), 307.

${ }^{145}$ Hollie Nyseth Brehm et al., "Age, Gender, and the Crime of Crimes: Toward a Life-course Theory of Genocide Participation," Criminology 54, no. 4 (2016), 722.
} 
indeed focus on how perceptions varied in more rural areas, which may have had lower levels of education among judges.

Taken together, these findings extend role theory, and gendered role theory, to a transitional justice setting. As hundreds of thousands of Rwandans filled the judges' benches, understanding how Inyangamugayo viewed their roles is important in its own right. However, this case can also speak to other cases of transitional justice and community courts worldwide.

\section{Acknowledgements}

This article was made possible thanks to the generosity of Aegis Trust programme in Research, Policy and Higher Education as well as DfID and SIDA as project funders. Rwanda's Inyangamugayo: Perspectives from Practitioners in the Gacaca Transitional Justice Mechanism* Jean-Damascène GASANABO, 1 Donatien NIKUZE, 2 Hollie NYSETH BREHM, 3 Hannah PARKS, 4 1\&2 Research and Documentation Center on Genocide, National Commission for the Fight against Genocide (CNLG), 3 Department of Sociology, The Ohio State University 4 Northeastern University *Direct correspondence to Jean-Damascène Gasanabo, Research and Documentation Center on Genocide, National Commission for the Fight against Genocide (CNLG), P.O. Box 7035 KIGALI, RWANDA, (email: jd.gasanabo@cnlg.gov.rw)

\section{Bibliography}

Baines, Erin K. "The Haunting of Alice: Local Approaches to Justice and Reconciliation in Northern Uganda." International Journal of Transitional Justice 1, no. 1 (2007), 91-114. Doi: 10.1093/ijti/ ijm007

Barker, Christine R., Elizabeth A. Kirk, and Monica Shah. Gender Perceptions and the Law. Aldershot: Ashgate Publishing, 1998.

Berry, Marie E. "When "Bright Futures" Fade: Paradoxes of Women's Empowerment in Rwanda." Signs: Journal of Women in Culture and Society 41, no. 1 (2015), 1-27. Doi: 10.1086/681899

Bornkamm, Paul Christoph. Rwanda's Gacaca Courts: Between Retribution and Reparation. London: Oxford University Press, 2012. Doi: 10.1093/acprof:oso/9780199694471.001.0001

Biddle, Bruce J. “Recent Developments in Role Theory." Annual Review of Sociology 12, no. 1 (1986), 67-92. Doi: 10.1146/annurev.so.12.080186.000435

Burnet, Jennie E. "Gender Balance and The Meanings of Women in Governance in Post-genocide Rwanda." African Affairs 107, no. 428 (2008), 361-386. Doi: 10.3138/gsp.3.2.173

--------. "The Injustice of Local Justice: Truth, Reconciliation, and Revenge in Rwanda." Genocide Studies and Prevention 3, no. 2 (2008), 173-193. Doi: 10.3138/gsp.3.2.173

Chakravarty, Anuradha. Investing in Authoritarian Rule: Punishment and Patronage in Rwanda's Gacaca Courts for Genocide Crimes. New York: Cambridge University Press, 2015. Doi: 10.1017/ CBO9781316018804

Clark, Phil. The Gacaca Courts, Post Genocide-Justice and Reconciliation in Rwanda: Justice Without Lawyers. Cambridge: Cambridge University Press, 2010. Doi: 10.1017/CBO9780511761584

Des Forges, Alison. Leave None To Tell the Story: Genocide in Rwanda. New York: Human Rights Watch, 1999, 6-591, Accessed July 23, 2020, https://www1.essex.ac.uk/armedcon/story id/ Leave \%20None \%20to\%20tell\%20the\%20story-\%20Genocide\%20in\%20Rwanda.pdf.

Doughty, Kristen Connor. Remediation in Rwanda: Grassroots Legal Forum. Philadelphia: University of Pennsylvania Press, 2016. Doi: 10.9783/9780812292398

Drumbl, Mark A. "Punishment, Postgenocide: From Guilt to Shame to 'Civis' in Rwanda." N.Y.U. Law Review 75 (2000), 1221-1326. Doi: 10.2139/ssrn.263314

Gahongayire, Liberata. "Combatting Gender Based Violence in Rwanda." International Journal of Development and Sustainability 1 no. 2 (2012), 417-436.

Gasibirege, Simon. "The Election of Inyangamugayo Judges: Break Up or Continuity?" Notes of the Conflict Management Centre 6, (2002), 93-127.

Gender Monitoring Office. The State of Gender Equality in Rwanda: From Transition to Transformation. Kigali: Gender Monitoring Office, 2019, 7-50. Accessed July 31, 2020. http://gmo.gov.rw/ fileadmin/user upload/Researches \%20and \%20Assessments/State $\% 20$ of $\% 20$ Gender $\% 20$ Equality\%20in\%20Rwanda.pdf 
Gibson, L. James. "Judges; Role Orientations, Attitudes, and Decisions: An Interactive Model." American Political Science Review, 72, no. 3 (1978), 911-924. Doi: 10.2307/1955111

Hintjens, M. Helen. "Explaining the 1994 Genocide in Rwanda." The Journal of Modern African Studies 37, no. 2 (1999), 241-286. Doi: 10.1017/S0022278X99003018

Honeyman, Catherine, Shakirah Hudani, Alfa Tiruneh, Justina Hierta, Leila Chirayath, Andrew Iliff, and Jens Meierhenrich. "Establishing Collective Norms: Potentials for Participatory Justice in Rwanda." Peace and Conflict: Journal of Peace Psychology, 10, no.1 (2004), 1-24. Doi: $10.1207 / \mathrm{s} 15327949$ pac1001 1

Howard, J. Woodford, Jr. "Role Perceptions and Behavior in Three US Courts of Appeals." The Journal of Politics 39, no. 4 (1977), 916-938. Doi: 10.2307/2129935

Ingelaere, Bert. Inside Rwanda's Gacaca Courts: Seeking Justice after Genocide. Madison: The University of Wisconsin Press, 2016.

---------. "The Gacaca Courts in Rwanda." In Traditional Justice and Reconciliation after Violent Conflict: Learning from African Experiences, edited by Huyse Luc and Mark Salter, 103-134. Stockholm: International Institute for Democracy and Electoral Assistance, 2008.

Law on the Crime of Genocide Ideology and Related Crimes of 2018 (Law No. 59/2018, August 22, 2018), 66-77. (Rep. of Rwanda). Accessed July 30, 2020. https://rwandalii.africanlii.org/ sites/default/files/gazette/OG\%2Bno\%2BSpecial\%2Bof\%2B25\%2B09\%2B2018.pdf.

Law on the Organization of Prosecutions for Offences constituting the Crimes of Genocide or Crimes against Humanity committed since October 1, 1990 of 1996 (Organic Law No. 8/96, August 30, 1996). (Rep. of Rwanda). Accessed July 30, 2020. https://reparations.qub.ac.uk/ assets/uploads/ORGANIC-LAW-No.pdf.

Longman, Timothy. "An Assessment of Rwanda's Gacaca Courts." Peace Review 21, no. 3 (2009), 304-312. Doi: $10.2307 / 2129935$

--------. Memory and Justice in Post-Genocide Rwanda New York: Cambridge University Press, 2017.

Lundy, Patricia. "Paradoxes and Challenges of Transitional Justice at the 'Local' Level: Historical Enquiries in Northern Ireland." Contemporary Social Science 6, no. 1 (2011), 89-105. Doi: $10.1080 / 17450144.2010 .534495$

Martin, Patricia Yancey, John R. Reynolds, and Shelley Keith. "Gender Bias and Feminist Consciousness Among Judges and Attorneys: A Standpoint Theory Analysis." Journal of Women in Culture and Society 27, no. 3 (2002), 665-701. Accessed July 3, 2020. Doi: $10.1086 / 337941$

Ministry of Local Government, Dénombrement des Victimes du Génocide. Final Report, Kigali: Rwandan Ministry of Local Government, 2004, 1-38.

National Itorero Commission, Imfashanyigisho yo gutoza Indangagaciro y'Ubunyangamugayo (Kigali: Ubutore Development Centre, National Itorero Commission, 2014), 1-28.

National Service of Gacaca Courts. Amasomo y'Inyangamugayo z'Inkiko Gacaca (Training of Inyangamugayo of Gacaca Courts). Kigali: National Service of Gacaca Courts, NovemberDecember, 2005, 1-93.

--------. Summary of the Report Presented at the Closing of Gacaca Courts Activities. Kigali: National Service of Gacaca Courts, 2012, 1-22.

Ngarambe, Telesphore. Practical Challenges in Customary Law Translation: The Case of Rwanda's Gacaca Law. Addis Ababa: Organization for Social Science Research in Eastern and Southern Africa, 2015.

Newbury, Catharine, Baldwin, Hannah. "Confronting the Aftermath of Conflict: Women's Organizations in Postgenocide Rwanda." In Women and Civil War: Impact, Organizations, and Action, edited by Krishna Kumar, 97-128. Boulder CO: Lynne Rienner, 2001.

Ní Aoláin, Fionnuala. The Oxford Handbook of Gender and Conflict. London: Oxford University Press, 2017. Doi: $10.1093 /$ oxfordhb/9780199300983.001.0001

Nyseth Brehm, Hollie, Christopher Uggen, and Jean-Damascène Gasanabo. “Genocide, Justice, and Rwanda's Gacaca Courts." Journal of Contemporary Criminal Justice 30, no. 3 (2014), 333352. Doi: $\underline{10.1177 / 1043986214536660}$

"Age, Gender, and The Crime of Crimes: Toward a Life-course Theory of Genocide Participation." Criminology 54, no. 4 (2016), 713-743. Doi: 10.1111/1745-9125.12122 
Nyseth Brehm, Hollie and Shannon Golden. "Centering Survivors in Local Transitional Justice." Annual Review of Law and Social Science 13, (2017), 101-121. Accessed July 22, 2020. Doi: 10.1146/annurev-lawsocsci-110316-113444

Oliveira Gomes, Adalmir, Tomas Aquino Guimaraes, and Eda Castro Lucas de Souza. "Judicial Work and Judges' Motivation: The Perceptions of Brazilian State Judges." Law E Policy 38, no. 2 (2016), 162-176. Doi: 10.1111/lapo.12050

Palmer, Nicola. Courts in Conflict: Interpreting the Layers of Justice in Post-Genocide Rwanda. New York: Oxford University Press, 2015. Doi: 10.1093/acprof:oso/9780199398195.001.0001

Porter, Elisabeth. Peacebuilding: Women in International Perspective (Routledge Advances in International Relations and Global Politics), 1st ed. New York: Routledge, 2007. Doi: 10.4324/9780203939994

Presidential Order Establishing Modalities for Organizing Elections of Members of "Gacaca Jurisdictions" Organs of 2001 (Presidential Order, No. 12/01 of June 26, 2001). (Rep of Rwanda). Rwandan Official Gazette No. 14, July 15, 2001.

Reyntjens, Filip. “Rwanda: Genocide and Beyond." Journal of Refugee Studies 9, no. 3 (1996), 240-251. Doi: $10.1093 / \mathrm{jrs} / 9.3 .240$

Rutayisire, Paul. Gacaca Courts in Rwanda. Kigali: Ministry of Justice, 2012.

Schultz, Ulrike and Gisela Shaw. Gender and Judging. Oxford: Hart Publishing, 2017.

Steffensmeier, Darrell and Chris Hebert. "Women and Men Policymakers: Does the Judge's Gender Affect the Sentencing of Criminal Defendants?" Social Forces 77, no. 3 (1999), 1163-1196. Accessed July 31, 2020, Doi: 10.2307/3005975.

Verwimp, Philip. "An Economic Profile of Peasant Perpetrators of Genocide: Micro level Evidence from Rwanda." Journal of Development Economics 77, no 2 (2005), 297-323. Doi: 10.1016/j. jdeveco.2004.04.005

Villa-Vicencio, Charles, Paul Nantulya, and Tyrone Savage. Building Nations: Transitional Justice in the African Great Lakes Region. Cape Town: Institute for Justice and Reconciliation, 2005.

Waldorf, Lars. "Mass Justice for Mass Atrocity: Rethinking Local Justice as Transitional Justice." Temple Law Review 79, (2006), 1-88.

Wierzynska, Aneta. "Consolidating Democracy through Transitional Justice: Rwanda's Gacaca Courts." N.Y.U. Law Review 79, no. 5 (2004), 1934-1970.

Yinger, Milton. Toward a Field Theory of Behavior: Personality and Social Structure. New York: McGraw Hill, 1965. 